\title{
POLEMIK HARUN NASUTION DAN H.M. RASJIDI DALAM MISTISISME ISLAM
}

\author{
A6dus Syakur \\ Fakultas Ushuluddin UIN Syarif Hidayatullah Jakarta \\ E-mail: abdussyakur1991@gmail.com
}

\begin{abstract}
Harun Nasution is known as a pioneer of academic Islamic studies in Indonesia, including the study of Islamic mysticism. However, H.M. Rasjidi criticized Harun Nasution. H.M. Rasijidi by assuming his views deviate from Islamic teachings. Based on this polemic, this paper focused on two main topics. First, the problem of legitimacy of Islamic mysticism. Second, al-ittihâd. This paper used a descriptive-analysis method with reference to the works of Harun Nasution and H.M. Rasjidi as primary data. Then, the data is compared by referring to supporting references to analyze their views further. This paper shows two conclusions according to the focus of this paper. First, H.M. Rasjidi considers that Islamic mysticism is not in accordance with Islamic teachings, because it emphasizes the aspects of influence from outside Islam. While, Harun Nasution viewed mysticism as an important aspect of Islam, because it was considered to have a strong source from the al-Qur'ân dan Hadith. Second, Harun Nasution views that al-ittihâd is the main goal of Islamic mysticism which philosophically describes the bond of servants to God. While, H.M. Rasjidi rejects the concept of al-ittihâd and is deemed deviating from Islamic teachings because it is considered to equate God with beings.
\end{abstract}

Harun Nasution dikenal sebagai penggerak kajian Islam secara akademis di Indonesia, termasuk kajian mistisisme Islam. Namun, H.M. Rasjidi mengritik Harun Nasution. H.M. Rasjidi menganggap pandangannya telah 
menyimpang dari ajaran Islam. Berdasarkan polemik tersebut, tulisan ini mengangkat dua masalah pokok. Pertama, legitimasi mistisisme Islam. Kedua, al-ittihâd. Kajian ini menggunakan motode deskriptif-analisis dengan merujuk kepada karya-karya Harun Nasution dan H.M. Rasjidi sebagai data primer. Kemudian, data tersebut dikomparasikan dengan cara merujuk kepada referensi pendukung untuk menganalisis pandangan mereka secara lebih jauh. Kajian ini menunjukkan dua kesimpulan. Pertama, H.M. Rasjidi memandang bahwa mistisisme Islam tidak sesuai dengan ajaran Islam karena lebih menekankan aspek keterpengaruhan dari luar Islam. Sementara Harun Nasution memandang bahwa mistisisme merupakan aspek penting dari Islam karena dianggap memiliki landasan kuat dari Alquran dan hadis. Kedua, Harun Nasution memandang bahwa alittihâd merupakan tujuan utama dari mistisisme Islam yang secara filosofis menggambarkan kedekatan hamba kepada Tuhan. Sementara H.M. Rasjidi menolak al-ittihâd dan dianggap menyimpang dari ajaran Islam karena dianggap menyamakan Tuhan dengan makhluk.

Keywords: Harun Nasution; H.M. Rasjidi; Islamic mysticism

Received: September 30, 2018; Accepted: November 15, 2018

\section{Pendahuluan}

Mistisisme Islam atau yang dikenal dengan istilah tasawuf atau sufisme memang mengalami berbagai perbedaan pendapat dalam perjalanan sejarahnya. Hal itu disebabkan di antaranya oleh perbedaan pendekatan terhadap sumber ajaran Islam, yakni Alquran dan hadis. Perbedaan pendekatan tersebut kemudian memunculkan respon yang berbeda terhadap tasawuf itu sendiri. Di satu sisi, ada yang memandang tasawuf bersumber dari ajaran Islam, yang kebanyakan dianut kalangan Islam tradisional (Bagir 2016; Masrur 2018; Faizin 2018). Namun di sisi lain, ada yang memandang bahwa ajaran tasawuf tidak bersumber dari ajaran Islam, yang banyak diadopsi oleh kalangan Salafî (Wahyudi 2008; Ruwaifi' 2011; al-Husaini 2013). Inilah yang menjadi perdebatan panjang masyarakat Muslim Indonesia hingga kini yang tidak kunjung usai.

Di samping itu, perbedaan telaah historis juga turut menyumbang bagian terhadap perbedaan di atas. Terdapat kalangan yang memandang bahwa sejarah kemunculan tasawuf dilatarbelakangi oleh penghayatan terhadap spirit paling agung dari ajaran Islam, sehingga memunculkan sikap 
reseptif. Namun, ada pula kalangan yang memandang bahwa kemunculan tasawuf tidak lain karena pengaruh dari luar ajaran Islam, sehingga menimbulkan sikap rejektif. Dari sisi akademis, perbedaan tersebut pada dasarnya adalah wajar selama diikuti pertangungjawaban argumentatif dari masing-masing pendapat.

Di Indonesia, perbedaan pendapat dalam tasawuf berjalan cukup lama seiring dengan sejarah kemunculan paham-paham modernis dan purifikatif di Nusantara. Dengan alasan purifikasi, mereka menafikan keberadaan tasawuf dalam Islam. Namun, ternyata tasawuf berkembang cukup pesat di Indonesia. Hal ini terbukti dengan munculnya beberapa lembaga tarekat yang berasal dari luar Nusantara, seperti Naqshabandiyah dan Qadiriyah di beberapa wilayah Indonesia. Bahkan, muncul pula tarekat yang bersifat lokal, seperti Wahidiyah, Shiddiqiyah, dan Syahadatain (Rosyid 2018).

Dalam dunia akademis, perbedaan itu terlihat pula dalam polemik yang terjadi antara Harun Nasution dan H.M. Rasjidi. Pada tahun 1970an Harun Nasution menulis sebuah buku berjudul Islam Ditinjau dari Berbagai Aspeknya sebagai salah satu upaya untuk melakukan pembaharuan pemikiran Islam di Indonesia. Beberapa tahun kemudian, setelah buku ini meluas, H.M. Rasjidi meluncurkan kritik tajam kepada Harun Nasution menyangkut cara pandangnya tertulis dalam bukunya tersebut. H.M. Rasjidi menulis buku secara khusus berisi kritik terhadap Harun dengan judul Koreksi terhadap Dr. Harun Nasution tentang Islam Ditinjau dari Berbagai Aspeknya. Melalui buku tersebut H.M. Rasjidi mengatakan bahwa pemikiran Harun Nasution sangat berbahaya bagi umat Islam (Syakur 2015, 49).

Beberapa hal yang diperdebatkan Harun Nasution dan H.M. Rasjidi dalam mistisisme Islam di antaranya adalah mengenai legitimasi ajaran tasawuf yang meliputi dasar-dasar ajaran tasawuf dan asal-usul ajaran tasawuf. Secara lebih khusus, mereka juga berbeda pendapat tentang kebersatuan manusia dengan Tuhan, yaitu al-ittihâd (mystical union) yang merupakan salah satu ajaran penting dalam mistisisme Islam. Kedua pembahasan ini akan dikaji secara kritis untuk mendapatkan gambaran polemik yang terjadi antara keduanya.

Kajian tentang pemikiran Harun Nasution dan H.M. Rasjidi memang sudah banyak dilakukan. Kajian-kajian tentang Harun Nasution lebih banyak menyoroti masalah teologi yang merupakan aspek sentral dalam pemikirannya, misalnya teologi Islam rasional (Abdullah 1997; Abdullah 1999; Mahmud 1998; Ariendonika 2002), teologi lingkungan 
(Bisri 2011), akal dan wahyu (Ibrahim 2016; Yanti 2017; Candra 2018), Harun Nasution dan Neo-Mu'tazilah (Mahribi 2018). Terdapat pula kajian yang membahas pemikiran Harun Nasution tentang pendidikan (Salahuddin 2000; Afendi 2010; Junni 2014; Sholehuddin 2010; Hidayat 2017; Firdaus 2017). Ada pula yang membahas tentang pemikiran tafsir Harun Nasution (Jamal 2012). Terdapat pula studi komparatif atas pemikiran Harun Nasution dengan pemikir lainnya, misalnya akal dan wahyu perspektif Harun Nastion dan Muhammad 'Abduh (Hutasuhut 2017), pemikiran filsafat Harun Nasution dan Nurcholis Madjid (Munir 2017), teologi Harun Nasution dan Nurcholish Madjid (Anwar 2005), sunnatullah perspektif Harun Nasution dan Nurcholish Madjid (Lubis 2002), dan perbedaan pemikiran Harun Nasution, Munawir Sjadzali, dan Nurcholish Madjid dalam masalah fikih (Alkhendra 2016). Sementara itu, ada pula tulisan yang membahas tentang pemikiran H.M. Rasjidi namun tidak sebanyak telaah terhdap pemikiran Harun Nasution, di antaranya adalah analisis terhadap pemikiran Nurcholish Madjid dan H.M. Rasjidi tentang sekularisasi (Syefriyeni 2013) dan pemikiran H.M. Rasjidi tentang metodologi pendidikan Islam (Syarief 2013).

Berbagai kajian di atas menunjukkan, baik studi atas pemikran Harun Nasution maupun H.M. Rasjidi, yang secara khusus membahas mistisisme memang belum banyak dilakukan, terlebih lagi studi komparatif atas pandangan keduanya. Padahal, sejarah mencatat bahwa keduanya pernah terlibat dalam polemik akademis pemikiran Islam yang termasuk di dalamnya membahas mistisisme Islam. Harun Nasution merupakan tipologi pemikir rasional dan sangat mengedepankan akal dalam memahami sesuatu. Ia tidak mau terjebak dalam makna tekstual teks Alquran dan hadis. Namun, kenyataan ini berbeda dengan H.M. Rasjidi yang mengedepankan sisi nalar "keislamannya", sehingga seringkali sangat terpaku pada makna tekstual teks. Inilah urgensi kenapa studi ini perlu dilakukan sekaligus sebagai refleksi atas perdebatan yang terjadi di masa sekarang ini. Studi komparatif atas pemikiran keduanya sebenarnya pernah dilakukan oleh penulis. Hanya saja, kajian tersebut lebih terfokus pada aspek filsafat dan teologi yang berbeda dengan fokus dalam tulisan ini yang lebih terkait dengan mistisisme Islam atau tasawuf (Syakur 2015).

\section{Perdebatan Legitimasi Mistisisme Islam: Dari Islam atau non-Islam?}

Para ahli berbeda pendapat mengenai asal-usul tasawuf. Ada yang berpendapat bahwa tasawuf berasal dari luar Islam, seperti dari kebudayaan 
Persia, Kristen, India, dan filsafat Yunani. Seorang orientalis seperti F.A.D. Tholukc, Reinhard P. Dozy, dan W.H. Palmer mengatakan bahwa tasawuf berasal dari kebudayaan Majusi, Persia (Schimmel 2003, 9). Argumen yang mereka kemukakan kerena di awal kemunculannya, para sufi banyak yang berasal dari Persia yang kemudian masuk Islam dan membawa ajaran Majusi dan kebudayaan Persia ke dalam Islam (al-Taftazânî 2008, 26).

Beberapa figur seperti Von Kremer, Ignaz Goldziher, Asin Palacios, Julian Baldick, Margareth Smith, dan Ibrâhîm Hilâl mengidentifikasi bahwa tasawuf berasal dari Kristen (Hilâl 1979, 3). Argumen yang mereka kemukakan salah satunya bahwa, praktik zuhd dalam tasawuf berasal dari kebiasaan rahib-rahib Kristen Timur sebelum kedatangan Islam. Bahkan, penggunaan kain wol (sûf) dalam tradisi sufi juga dianggap berasal dari tradisi Kristen (Schimmel 2003, 10).

Selain pendapat yang mengatakan tasawuf berasal dari Majusi dan Kristen seperti dipaparkan di atas, terdapat pula pendapat yang mengklaim bahwa asal mula tasawuf adalah dari Budha. Horton dan Richard Hartmann, sebagai disampaikan al-Taftazânî menyatakan bahwa tasawuf bersumber dari India. Mereka memandang bahwa terdapat beberapa konsepsi dan praktik-praktik dalam tasawuf yang memiliki kesamaan dengan ajaran-ajaran Budhisme India (al-Taftazânî 2008, 31).

Terakhir, banyak yang mengakui bahwa tasawuf Islam sangat terpengaruh oleh filsafat neo-Platonisme. Akan tetapi pengaruh tersebut hanya tampak pada tasawuf falsafi (theosophical mysticisme) yang muncul pada kurun abad ke-3 H., sebagaimana Dhû al-Nûn al-Miṣrî atau yang serupa dengannya (al-Taftazânî 2008, 33). Islam mulai bersinggungan dengan filsafat Yunani sejak penerjemahan besar-besaran pada masa pemerintahan 'Abbâsiyyah. Tidak menutup kemungkinan bahwa pengaruh pemikiranpemikiran Yunani, khususnya filsafat neo-Platonis, meresap ke dalam Islam, termasuk ke dalam ajaran tasawuf (Schimmel 2003, 8).

Harun Nasution sebenarnya juga menyadari bahwa asal usul sufisme memang menjadi perdebatan. Harun Nasution mengungkapkan bahwa ada yang berpendapat sufisme berasal dari ajaran Islam sendiri. Ada pula yang berpendapat bahwa sufisme berasal dari luar Islam yang kemudian diadopsi oleh Islam (Nasution 1985, 69). Terlepas dari perdebatan tersebut, Harun Nasution memandang bahwa sufisme adalah aspek penting dalam Islam yang muncul dari ajaran Islam sendiri. Oleh karena itu, ajaran sufisme dipandang memiliki landasan baik dalam Alquran maupun hadis (Nasution 1985, 44-46). 
Pandangan Harun Nasution di atas mendapat penolakan dari H.M. Rasjidi. H.M. Rasjidi memandang bahwa Islam pada dasarnya tidak menganjurkan praktik-praktik mistik. Dengan demikian, keberadaan sufisme, yang disepakati sebagai mistisisme Islam juga ditolak oleh H.M. Rasjidi. Di dalam Alquran maupun hadis tidak ditemukan dalil-dalil yang secara tekstual menganjurkan praktik-praktik mistik tersebut. Jika demikian, jelas bahwa sufisme tidak memiliki landasan di dalam Islam. Dalam kritiknya, H.M. Rasjidi mengatakan "Dengan begitu, maka mistisisme bukan semata-mata aspek Islam. Islam adalah ajaran Tuhan untuk mengatur hubungan masyarakat, yakni hubungan manusia dengan manusia serta mengatur hubungan manusia dengan Tuhan melalui tuntunan ibadah-ibadah" (Rasjidi 1997, 123).

Dari kutipan di atas, H.M. Rasjidi ingin menjelaskan bahwa Islam mengatur hubungan manusia dengan Tuhan (habl min Allâh) melalui tuntunan ibadah-ibadah. Hubungan antara manusia dengan Allah tampak dalam ibadah-ibadah mahdah, seperti melaksanakan salat, puasa, dan sebagainya. Pendekatan diri kepada Allah bisa ditempuh dengan melaksanakan ibadah-ibadah tersebut yang secara praktis dapat dilihat dari Alquran dan hadis, tanpa harus melalui cara yang ditempuh oleh para sufi. Oleh karena itu, pantas apabila H.M. Rasjidi memandang bahwa mistisisme tidak memiliki dasar dalam Islam.

Harun Nasution memiliki argumen lain. Menurut Harun Nasution, salah satu tujuan terpenting dalam ajaran sufisme adalah berusaha sedekat mungkin kepada Allah. Hal tersebut didasarkan pada perintah Alquran agar manusia selalu dekat kepada Allah. Paham bahwa Tuhan sangat dekat dengan manusia didasarkan pada ayat-ayat Alquran sebagai berikut:

"ika hamba-hambaku bertanya tentang diri-Ku, maka sesungguhnya Aku dekat. Aku mengabulkan seruan orang-orang yang memanggil, jika ia memanggilku" (Q.S. Qâf [50]: 16). Di ayat lain dikatakan, "Sebenarnya Kami ciptakan manusia dan Kami tahu apa yang dibisikkan dirinya kepadanya. Kami lebih dekat kepadanya lebih dari pembuluh darahnya sendiri" (Q.S. al-Baqarah [2]: 186).

Menurut Harun Nasution, ayat-ayat semacam di atas tidak sekedar menunjukkan bahwa Tuhan sangat dekat dengan manusia, tetapi juga mengandung anjuran agar manusia selalu dekat kepada Tuhan. Kalau demikian, tidak ada yang salah dengan faham sufisme. Dengan alasan itulah 
Harun Nasution memandang bahwa sufisme memiliki dasar dalam Islam. Kemudian Harun Nasution mengatakan:

"Bagaimanapun paham bahwa Tuhan dengan menusia, yang merupakan ajaran dasar dalam mistisisme, terdapat dalam al-Qur'an dan hadits. Jadi, terlepas dari kemungkinan ada atau tidak ada pengaruh dari luar, ayat-ayat di atas dapat membawa kepada kemunculan aliran sufi dalam Islam, yaitu kalau yang dimaksud dengan sufisme ialah ajaran-ajaran tentang berada sedekat mungkin pada Tuhan" (Nasution 1985, 47).

Pandangan Harun Nasution sejalan dengan apa yang dikatakan oleh al-Taftazânî. Memang tidak bisa dipungkiri bahwa Islam bersinggungan dengan tradisi Persia, Kristen, India, filsafat Yunani, dan tradisi yang lain. Akan tetapi, tidak bisa digeneralisasikan bahwa tasawuf berasal dari luar Islam. Al-Taftazânî memandang bahwa tasawuf merupakan pengalaman spritual yang bisa dicapai oleh setiap orang. Tidak menutup kemungkinan pengalaman para sufi memiliki kesamaan dengan orang lain atau dengan ajaran dan kebudayaan lain. Keserupaan antara tasawuf Islam dan mistisisme lainnya tidak menandakan bahwa tasawuf Islam mengambil ajaran mistisisme dari di luar agama Islam. Pendapat al-Taftazânî disandarkan kepada pendapat sarjana besar dalam mistisisme Islam lainnya, seperti Nicholson, Louis Massignon, dan Spencer Trimingham. Sebagaimana dijelaskan oleh al-Taftazânî, mereka memandang bahwa tasawuf Islam lahir dari rahim Islam sediri (al-Taftazânî 2008, 36-39). Tasawuf Islam tidak lain bersumber dari Alquran dan hadis serta nilai-nilai luhur lain yang berasal dari tradisi Islam sendiri.

Reynold A. Nicholson, yang merupakan sarjana sufisme ternama abad kontemporer melihat bahwa bentuk-bentuk dan konsep-konsep sufisme Islam tidak lain berasal dari Islam itu sendiri. Namun demikian, Nicholson juga tidak memungkiri adanya pengaruh pemikiran ketimuran kuno seperti Kristen dan neo-Platonisme yang telah meresap ke dalam Islam, bahkan pada tahap yang paling awal (Schimmel 2003, 10).

Berdasarkan uraian di atas jelas, Harun Nasution memiliki alasan kuat untuk mengklaim bahwa ajaran tasawuf memang lahir dari Islam sebagai ekspresi pendekatan diri kepada Tuhan. Sebaliknya, klaim H.M. Rasjidi belum memiliki dasar yang kuat. Apalagi, dalam kritiknya terhadap Harun Nasution, H.M. Rasjidi memang tidak menghadirkan argumen yang memadai untuk menolak pandangan Harun Nasution. Ia hanya memberikan argumen "normatif" untuk menolak tasawuf. 
Dalam tataran yang lebih dalam, H.M. Rasjidi tidak hanya menolak pandangan tentang asal-usul ajaran tasawuf, tetapi ia juga menolak berbagai praktik yang terdapat di dalamnya. Ketika Harun Nastion menjelaskan tentang zuhd, H.M. Rasjidi juga mengritiknya.

Harun Nasution menjelaskan bahwa seorang sufi harus melalui tahapan-tahapan (al-maqâm) tertentu untuk mendekatkan diri kepada Tuhan. Harun Nasution menyebut maqâm meliputi lima hal yaitu taubat, zuhd, sabar, tawakkal, dan ridâa (Nasution 2010, 48). Salah satu ciri terpenting yang harus dimiliki seorang sufi adalah zuhd. Bahkan, menurut Harun Nasution, seseorang tidak bisa menjadi sufi kecuali menjadi zâhid terlebih dahulu (Nasution 1985, 77).

Salah satu tokoh sufi klasik yang diangkat oleh Harun Nasution berkenaan dengan zuhd adalah Ibrâhîm ibn Adhâm (w. 777 M) dan Bishr alHâfî (w. 227 H). Ibrâhîm ibn Adhâm mengatakan bahwa al-faqr (kemiskinan) adalah harta yang disimpan Tuhan di surga dan tidak dianugerahkan kecuali kepada orang yang dicintai-Nya. Bishr al-Ḥâfi dikisahkan bahwa ketika dia sakit, dia memberikan bajunya kepada orang miskin yang juga sedang sakit, sehingga dia meninggal dalam keadaan tanpa baju (Nasution 1985, 74).

H.M. Rasjidi secara tegas memberikan komentar terhadap konsepsi dan praktik zuhd seperti dikemukakan Harun Nasution di atas. H.M. Rasjidi menilai bahwa apa yang dilakukan oleh Ibrâhîm ibn Adhâm dan Bishr al-Hâfî tidak sesuai dengan ajaran Islam, bahkan itu hanya dilakukan oleh orang yang sinting (Rasjidi 1997, 123). Padahal, menurut H.M. Rasjidi, Allah berfirman di dalam Alquran:

"Dan berharaplah dari anugerah yang telah Tuhan berikan kepadamu untuk mencapai akhirat dan jangan lupa nasibmu di dunia" (Q.S. al-Qașaṣ [28]: 77).

Kesimpulan H.M. Rasjidi bahwa praktik zuhd itu dianggap meyimpang dari ajaran Islam, tentu merupakan kesimpulan yang ekstrim. Dalam ajaran sufi, sebagaimana disampakain al-Qushayrî dalam al-Risâlat alQushayriyyah, zuhd ialah membatasi keinginan terhadap dunia dan bukan meninggalkan dunia (al-Qushayrî 2013, 151). Dengan kata lain, zuhd adalah tidak terlalu tertarik pada dunia, tetapi lebih berotientasi terhadap akhirat. Bukan berarti tidak mementingkan dunia sepenuhnya, tetapi meninggalkan dunia jika itu akan merusak orientasi ukhrawi. Itu semua sudah secara tegas dijelaskan dalam berbagai literatur tasawuf klasik diikuti dengan landasan 
Alquran dan hadis. Mengenai Ibrâhîm ibn Adhâm dan Bishr al-Hâfî, sebagaimana diangkat oleh Harun Nasution, justru al-Qushayrî meletakkan nama-nama tersebut di garda terdepan dalam al-Risâlat al-Qushayriyyah sebagai "guru sufi" (mashâyikh al-ș̂ffiyyîn) yang mengawali kemunculan ajaran tasawuf di dalam Islam (al-Qushayrî 2013, 22 \& 30).

Dengan merujuk kepada al-Risâlat al-Qushariyyah tentu apa yang dipaparkan Harun Nasution tentang zuhd jelas tidak sembarangan dan dapat dilacak sumbernya dalam berbagai literatur tasawuf klasik. Dalam waktu yang sama, tentu apa yang dituduhkan H.M. Rasjidi bahwa zuhd dianggap menyimpang dari ajaran Islam tidak dapat diterima.

Selain zuhd, H.M. Rasjidi juga mengritik penjelasan Harun Nasution tentang konsep penyucian jiwa. Harun Nasution berpendapat bahwa pada dasarnya roh itu suci karena berasal dari Tuhan. Karena roh itu suci, maka selalu mengajak kepada kesucian. Badan, karena memiliki hawa nafsu, bisa membawa kepada kejahatan. Roh akan kembali ke "sisi Tuhan yang Maha Suci” asalkan tetap dalam keadaan suci (Nasution 2013, 24).

H.M. Rasjidi mengritik pandangan Harun Nasution di atas dengan mengatakan bahwa paham tersebut berasal dari ajaran neo-Platonisme dan sama sekali tidak sesuai dengan ajaran Islam. H.M. Rasjidi mengatakan "Pengertian yang diterangkan Harun Nasution bukan pengertian Islam, tetapi pengertian neo-Platonisme yang banyak berhubungan dengan teori emanasi (al-fayd) dan gnostisisme" (Rasjidi 1997, 122).

H.M. Rasjidi menjelaskan bahwa menurut ajaran Islam, manusia bukan berasal dari Tuhan, tetapi diciptakan oleh Tuhan melalui kekuasaan dan kehendak-Nya (Rasjidi 1997, 123 \& 128). Roh tidak selalu baik dan badan tidak selalu jahat. Badan tidak memunyai hawa nafsu dan kecenderungan, tetapi bersifat netral. Jika roh baik, maka badan akan baik dan jika rohnya jahat, maka badan akan jahat. Jiwa, nafs atau roh itulah yang memiliki kecenderungan berbuat baik atau buruk. Di dalam Alquran diterangkan bahwa nafsu ada yang disebut dengan nafs ammârah, yang memerintahkan kepada kejahatan, nafs lawwâmah, nafsu yang selalu mencela orang lain, dan nafs al-mutma'innah, nafsu yang tentram (Rasjidi 1997, 43). Jiwa atau roh manusia menjadi kotor apabila dia melanggar larangan-larangan Tuhan. Apabila jiwa terpengaruh oleh setan, maka badan pun akan terpengaruh untuk melakukan kejahatan. Kalau roh itu mati, bukan kembali ke tempat asalnya, tetapi menghadap Tuhan untuk bertanggungjawab atas segala perbuatannya. Kalau dia baik, maka dia akan 
mendapat pahala di surga. Kalau dia jahat, maka dia akan disiksa di neraka (Rasjidi 1997, 35).

H.M. Rasjidi juga mengritik perkataan Harun Nasution yang mengatakan bahwa manusia yang berasal dari Tuhan, akan kembali ke "sisi Tuhan yang Maha Suci." Menurut H.M. Rasjidi, ungkapan Harun Nasution tersebut tidak sesuai dengan ajaran Islam. Istilah "sisi Tuhan" menurut H.M. Rasjidi berasal dari Injil (Lukas, 20 \& 42). Begitupun dengan istilah yang "Maha Suci" merupakan terjemahan dari kata "holy" dalam doktrin Kristen (Rasjidi 1997).

Kesimpulan seperti yang dikemukakan H.M. Rasjidi sudah banyak dikemukakan oleh para orientalis sebagaimana dilihat di awal. Misalnya Margaret Smith dan Julian Baldick yang memandang bahwa, baik secara historis maupun secara konseptual, ajaran sufisme berasal dari luar Islam, lebih khusus dari ajaran Kristen (Smith 2007; Baldick 1992). Analisis mereka lebih ditekankan kepada pendekatan historis dan studi komparatif ajaran sufisme dengan mistisisme dalam agama-agama, tanpa banyak mempertimbangkan landasan Alquran dan hadis yang dikemukakan oleh para sufi.

Kritik H.M. Rasjidi di atas merupakan upaya untuk membuktikan bahwa sufisme sebagaimana digambarkan Harun Nasution tidak memiliki landasan sama sekali di dalam Islam. H.M. Rasjidi ingin mengatakan bahwa sufisme muncul karena pengaruh dari luar Islam, seperti paham filsafat Yunani (neo-Platonis) dan doktrin Kristen.

Meskipun demikian, kalau merujuk kepada literatur-literatur tasawuf klasik Islam, maka tidak akan didapatkan kesimpulan yang demikian. Pembahasan utama dalam literatur-literatur tasawuf klasik biasanya menyangkut proses penyucian diri dan pendekatan diri kepada Allah yang meliputi taubat, zuhd, sabar, tawakkal, ridâ, dan sebagainya yang semuanya itu dipandang bersumber dari ajaran Islam dan selalu diikuti dalil naqliyyah yang diambil dari Alquran dan hadis.

\section{Perdebatan al-Ittihâad: Selaras Ajaran Islam atau Bukan?}

Menurut Harun Nasution, sufisme adalah kesadaran akan keberadaan komunikasi dengan Tuhan dan mengambil bentuk sangat dekat dengan Tuhan, dalam arti "bersatu" dengan Tuhan. Hal ini dapat dilihat dari uraian Harun Nasution dalam mengemukakan definisi mistisisme:

"Tujuan dari mistisisme, baik yang di dalam maupun di luar Islam, ialah memeroleh hubungan langsung dan disadari dengan Tuhan, sehingga di sadari 
benar bahwa seseorang berada di hadirat Tuhan, dengan mengasingkan diri dengan berkontemplasi. Kesadaran itu selanjutkan mengambil bentuk rasa dekat sekali dengan Tuhan dalam arti bersatu dengan Tuhan yang dalam Istilah Arab disebut al-ittihâd dan istilah inggris mystical union" (Nasution 1985).

Harun Nasution menggunakan kata alittihâd atau mystical union untuk menggambarkan inti ajaran sufisme, yakni agar manusia mencapai tujuan bersatu dengan Tuhan. Bagi Harun Nasution, alittihâd adalah puncak dari perjalanan spiritual yang ditempuh oleh para sufi. Dalam literatur tasawuf, istilah al-ittihâd selalu disandarkan kepada tasawuf Abû Yazîd al-Bustâmî. Akan tetapi berdasarkan pengertian di atas, Harun Nasution menggunakan istilah al-ittihâd untuk menggambarkan "kebersatuan manusia dengan Tuhan" secara umum. Harun Nasution mengatakan bahwa kebersatuan manusia dengan Tuhan bisa mengambil bentuk al-hulûl dan wah̆dat al-wujûd. Harun Nasution berpendapat, untuk mencapai tujuan "bersatu dengan Tuhan," ada beberapa proses dan tingkatan yang harus dilalui seorang sufi, yang pertama adalah al-maqâmât dan al-hâl (Nasution 1985). Setelah itu, seorang sufi akan sampai pada tingkatan al-mahabbah dan al-ma'rifah (Nasution 2010). Kedua hal tersebut adalah satu kesatuan yang tidak dapat dipisahkan. Kedua hal itu menggambarkan keberadaan hubungan yang sangat dekat antara manusia dengan Tuhan (Nasution 1985).

Pada tingkatan al-mahabbah, hati seseorang kosong dari segalagalanya, kecuali dari yang dicintai, yaitu Allah. Dalam keadaan ini, ia hidup hanya untuk beribadah kepada Allah. Kebanyakan orang melakukan ibadah karena takut kepada Allah dan takut kepada ancaman-ancaman-Nya di akhirat. Sementara bagi para sufi, Tuhan tidak untuk ditakuti, melainkan Zat yang harus dicintai dan didekati. Oleh karena itu, para sufi beribadah dan menjauhi hal-hal yang bersifat duniawi bukan karena takut, melainkan karena cinta kepada Allah (Nasution 1985).

Al-mahabbah senantiasa didampingi oleh al-ma'rifah. Al-mahabbah menggambarkan rasa cinta kepada Allah, sementara al-ma'rifah menggambarkan keadaan mengetahui Tuhan (Nasution 1985). Dalam tingkatan ini, seorang sufi berhadapan langsung dengan Tuhan. Dengan kata lain, seorang sufi telah mampu "melihat" Tuhan melalui kemampuan intuitifnya.

Konsep al-mahabbah, sebagaimana dijelaskan Harun Nasution, mendapat kritik dari H.M. Rasjidi. Harun Nasution menjelaskan bahwa 
pada tingkatan al-mahabbah, para sufi beribadah kepada Allah bukan karena takut, melainkan karena cinta. Allah bukan untuk ditakuti, tetapi untuk dicintai dan dikasihi (Nasution 1985).

Menurut H.M. Rasjidi, ungkapan tersebut tidak sesuai dengan ajaran Islam. Bahkan dalam hal ini, H.M. Rasjidi juga mengidentifikasi Harun Nasution telah terpengaruh oleh doktrin Kristen. Harun Nasution mengatakan dalam ajaran sufisme "Tuhan bukan suatu Zat yang ditakuti, melaikan untuk dicintai dan dikasihi." Menurut H.M. Rasjidi, ungkapan tersebut jelas bersumber dari doktrin Kristen. H.M. Rasjidi mengatakan bahwa istilah "Cinta" yang digunakan Harun Nasution berasal "God is Love" dalam doktrin Kristen (Rasjidi 1997).

H.M. Rasjidi mengatakan bahwa dengan jelas Alquran menggunakan kata ittaqâ untuk menggambarkan rasa takut kepada Allah. Alquran juga menggunakan kata khashiya dan khawf yang secara harfiah mengandung arti takut kepada Allah. Rasa takut tersebut berarti hormat dan cinta kepada Allah. Dengan demikian, H.M. Rasjidi memandang bahwa rasa takut kepada Allah sudah meliputi rasa cinta kepada Allah (Rasjidi 1997).

Menurut Harun Nasution, pada tingkatan al-ma'rifah, hakikatnya seorang sufi sudah benar-benar dekat kepada Tuhan. Untuk sampai pada tingkatan alittihâd hanya dibutuhkan satu langkah lagi, yaitu al-fanâ' dan albaqấ' (Nasution 2010). Harun Nasution mengatakan bahwa al-ittihâd merupakan kelanjutan dari al-fanâ' dan al-baqâ'. Harun Nasution menuliskan:

"Al-fanâ' adalah penghancuran perasaan atau kesadaran seseorang tentang dirinya dan tentang makhluk lain di sekitarnya. Sebenarnya dirinya dan makhluk lain masih tetap ada, tetapi tidak lagi disadari tentang wujud mereka, bahkan tentang wujud dirinya sendiri. Ketika itulah seorang sufi sampai kepada al-baqâ' atau kelanjutan wujud dalam diri Tuhan. Di situ pulalah tercapai alittihâd" (Nasution 1985).

Sebagaimana telah diketahui bahwa al-ittihâd sering disandarkan kepada Abû Yazîd al-Bustâmî. Ketika sampai kepada al-ittihâd, al-Bustâmî mengeluarkan kata-kata yang ganjil, yang dalam istilah tasawuf dikenal dengan shatahât. Al-Bustâmî mengatakan "Maha Suci Aku, Maha Suci Aku, Maha Besar Aku." Harun Nasution memandang bahwa yang mengucapkan kata tersebut bukan lagi al-Busțâmî, karena ia telah fanâ' dalam diri Tuhan. Al-Bustâmî tidak ada lagi, yang ada hanyalah Tuhan (Nasution 1985). 
Persatuan manusia dengan Tuhan selanjutnya, menurut Harun Nasution, bisa mengambil bentuk al-hulûl (mengambil tempat) sebagaimana dialami oleh al-Hallâj. Al-hulûl adalah sebuah paham yang meyakini bahwa Allah memilih manusia-manusia tertentu untuk mengambil tempat di dalamnya. Paham ini didasarkan atas keyakinan bahwa Tuhan memiliki sifat kemanusiaan (nâsût), dan sebaliknya manusia juga memiliki sifat ketuhanan (lâhût). Dalam keadaan inilah sifat manusia bersatu dengan sifat Tuhan. Sebelum mencapai persatuan dengan Tuhan, seorang sufi terlebih dahulu harus menghancurkan sifat-sifat kemanusiaannya, sehingga yang terdapat dalam dirinya hanyalah sifat-sifat ketuhanan. Di saat itulah baru Tuhan mengambil tempat dalam diri sufi yang bersangkutan. Sebagaimana al-Bustâmî, al-Ḥallâj juga mengeluarkan kata-kata ganjil. Ia mengatakan "Ana al-Haqq" (Aku adalah al-Haqq). Yang dimaksud Ana al-Haqq di situ bukan lagi al-Hallâj, tetapi ia mengucapkan kata tersebut atas nama Tuhan (Nasution 1985). Dengan kata lain, al-Hallâj berkata "Aku adalah Tuhan." Dalam kondisi tersebut, bukan lagi al-Hallâj yang mengatakan, karena ia teleh melebur dalam diri Tuhan.

Harun Nasution menjelaskan bahwa al-hulûl di atas didasarkan pada hadis yang artinya "Tuhan menciptakan Adam menurut bentuk-Nya." Dengan demikian, dalam diri Adam terdapat bentuk Tuhan, dan dalam diri Tuhan juga terdapat bentuk Adam (Nasution 1985). Atas dasar itulah persatuan Tuhan dengan manusia dapat terjadi.

Di samping al-hulûl, persatuan manusia dengan Tuhan juga mengambil bentuk wahdat al-wujûd yang dibawa oleh Muhy al-Dîn Ibn 'Arabî. Kalau dalam al-hulûl terdapat nâsût dan lâhût, maka dalam wahdat alwujûd terdapat istilah al-khalq (makhluk) dan al-Haqq (Tuhan). Dua hal ini merupakan dua aspek semua wujud. Wahdat al-wujûd didasarkan atas paham bahwa Allah ingin melihat diri-Nya di luar diri-Nya, sehingga Allah menciptakan alam. Artinya, alam semesta merupakan manifestasi dari Allah. Karena setiap benda yang ada di alam semesta esensinya adalah sifat ketuhanan-Nya, maka Allah melihat diri-Nya. Meskipun alam semesta terlihat banyak, pada sejatinya ia adalah satu wujud. Lebih dari sekedar alhulûl yang hanya mengonsepsikan persatuan manusia dengan Allah, waḥdat al-wujûd mengonsepsikan bahwa alam semesta adalah satu wujud dengan Allah (Nasution 1985).

Pandangan Harun Nasution di atas menunjukkan bahwa sungguhpun konsepsi-konsepsi tersebut berasal dari berbagai tokoh dan 
memiliki pengertian yang berbeda-beda, tetapi Harun Nasution memandang bahwa itu memiliki satu tujuan. Sebagaimana diketahui, alittihâd sendiri berasal dari al-Bustâmî, al-ḥulûl berasal dari al-Hallâj, dan wahdat al-wujûd berasal dari Ibn 'Arabî. Harun Nasution memandang bahwa aspek tersebut merupakan tujuan penting dalam ajaran sufisme, yaitu bersatu dengan Tuhan.

Pandangan Harun Nasution tersebut ditentang keras oleh H.M. Rasjidi. Memang H.M. Rasjidi tidak memberikan kritik secara rinci terhadap tiga bentuk persatuan manusia dengan Tuhan sebagaimana dikonsepsikan Harun Nasution, namun H.M. Rasjidi hanya menegaskan bahwa paham "bersatu dengan Tuhan" tidak memiliki landasan di dalam Islam. H.M. Rasjidi mengatakan:

"Tujuan bersatu dengan Tuhan bukan ajaran Islam. Tuhan itu Tuhan dan manusia itu hamba. Akan tetapi ada suatu hadis yang mengatakan "jika seseorang melakukan ibadah yang wajib dan yang sunnah dengan baik, maka segala tindakannya akan diarahkan oleh Tuhan kepada hal yang baik. Seakanakan Tuhan menjadikan kupingnya untuk mendengar dan menjadikan matanya untuk melihat." Kedaan semacam itu bukan persatuan manusia dengan Tuhan" (Rasjidi 1997).

H.M. Rasjidi juga menolak bahwa konsepsi bersatu dengan Tuhan yang dikatakan berdasarkan hadis "Tuhan menciptakan Adam menurut bentuknya." H.M. Rasjidi mengatakan bahwa ungkapan tersebut bukanlah hadis, tetapi berasal dari Injil, dalam Kitab Kejadian (Rasjidi 1997). Oleh karena itu, interpretasi tersebut jelas bertentangan dengan Alquran. Padahal Alquran mengatakan bahwa "tidak ada sesuatu apa pun yang serupa dengan Tuhan” (Q.S. al-Shûrâ [42]: 12).

Mengenai kritik di atas, nampaknya H.M. Rasjidi salah persepsi terhadap penjelasan Harun Nasution. Padahal secara tegas Harun Nasution mengatakan bahwa dalam alittihâd yang dimaksud antara manusia dengan Tuhan tetap merupakan wujud yang berbeda, tetapi yang disadari hanyalah wujud Tuhan (Nasution 1985). Artinya, alittihâd tidak berarti manusia serupa dengan Tuhan, tidak juga berarti bahwa manusia tidak dapat dibedakan dari Tuhan.

Namun demikian, H.M. Rasjidi tetap memandang bahwa hal itu tidak memiliki dasar dalam Islam. H.M. Rasjidi memandang, bagaimanapun bentuknya, konsepsi bersatu dengan Tuhan memiliki persamaan dengan tujuan mistisisme Kristen. Dalam keyakinan Kristen, 
setiap pemeluknya ingin bersatu dengan Yesus. Di samping itu, konsepsi tersebut juga dianggap memiliki kesamaan dengan tujuan "Kebatinan" yang dikenal dengan prinsip "manunggaling kawula Gusti” (Rasjidi 1997). Semuanya itu jelas-jelas tidak sesuai dengan ajaran Islam.

Mengenai pandangan H.M. Rasjidi tentang persoalan ini, tampak terdapat inkonsistensi atau lebih tepatnya perubahan pemikiran dalam diri H.M. Rasjidi. Sebelum berpolemik dengan Harun Nasution, H.M. Rasjidi tampak memiliki pandangan yang berbeda mengenai kebersatuan manusia dengan Tuhan. Dalam tulisan lain, yang ditulis sebelum kritik terhadap Harun Nasution, H.M. Rasjidi mengatakan:

"Bersatunya manusia dengan Tuhan itu hanya sedikit sekali disebut dalam alQur'an. Bersatunya manusia dengan Tuhan bukan tujuan manusia, seperti dilukiskan oleh aliran kebatinan, melainkan sebagai anugerah Tuhan kepada seseorang yang sangat istimewa, yang telah memenuhi syarat-syaratnya (Rasjidi 1972). Bersatunya seseorang dengan Tuhan tidak merupakan aspek yang mudah dicapai, mungkin seorang dalam sejuta" (Rasjidi 1972).

Kutipan di atas melukiskan gambaran yang berseberangan dengan kritik yang disampaikan kepada Harun Nasution. Berdasarkan ungkapan di atas, sekurang-kurangnya H.M. Rasjidi masih memberikan lampu hijau untuk mengakui bahwa kebersatuan manusia dengan Tuhan-meskipun sangat jarang tejadi-adalah mungkin. Bahkan H.M. Rasjidi juga tidak mengingkari bahwa hal tersebut memiliki landasan dalam Alquran. Akan tetapi dalam kritiknya terhadap Harun Nasution, H.M. Rasjidi menolak sama sekali konsepsi tersebut. Di satu sisi ia menerima konsep al-ittihâd dan di sisi lain tampak menolak secara total.

Penolakan terhadap konsepsi alittihâd bukanlah hal baru dalam sejarah tasawuf. Komentar senada pernah dikemukakan oleh al-Ghazâlî terhadap para sufi, terutama terhadap al-Hallâj dan al-Busțâmî karena ungkapan shatahât yang mengindikasikan kebersatuan dengan Tuhan. AlGhazâlî dengan tegas mengatakan bahwa ungkapan tersebut berbahaya dan tidak sesuai dengan ajaran agama (al-Ghazâlî 1998). Sebagai seorang yang fanatik terhadap Sunnî, maka tidak mengherankan apabila H.M. Rasjidi menolak konsepsi semacam itu.

Persolan di atas memang sudah menjadi isu klasik yang melibatkan pertentangan para sufi dan kalangan syariat. Hal itu dibuktikan dengan fakta bahwa al-Bustâmî dan al-Ḥallâj mati terbunuh karena ajarannya dianggap sesat. Oleh karena itu, tidak heran apabila kemudian H.M. Rasjidi 
mengatakan bahwa Harun Nasution menampilkan "segi-segi negatif" khususnya dalam bidang tasawuf (Rasjidi 1997).

Untuk menanggapi persoalan di atas, ada sebuah pendekatan falsafi yang mungkin bisa dijadikan pijakan. Secara ontologis, Tuhan adalah Zat yang bersifat transenden-immaterial yang berada dalam wilayah metafisika, sementara manusia adalah makhluk fisik yang bersifat material-indrawi. Dilihat dari aspek ini, maka mustahil manusia bisa bersatu dengan Tuhan. Di samping sebagai wujud materi, manusia juga sebagai wujud metafisika, maka dari aspek ini persatuan manusia dengan Tuhan bukan hal yang mustahil. Artinya, persatuan manusia dengan Tuhan tidak berarti bersatu secara fisik, melainkan secara metafisik. Persatuan manusia dengan Tuhan bukan dalam arti homogen, di mana manusia dan Tuhan tidak dapat dibedakan. Akan tetapi dalam arti heterogen, di mana manusia dengan Tuhan tetap diyakini sebagai unsur yang berbeda.

Dalam tasawuf, Allah dipandang sangat dekat kepada manusia, bahkan dikatakan lebih dekat daripada urat nadi atau pembuluh darahnya sendiri, aqrabu ilayhi min habl al-warîd (Q.S. Qâf [59]: 16), sebagaimana telah disampaikan Harun Nasution sebelumnya. Pembuluh darah mengalir dalam tubuh manusia, sementara Allah dikatakan lebih dekat (aqrabu) daripada sesuatu yang berada dalam diri manusia sendiri. Dengan demikian, ungkapan yang sesuai untuk pengertian tersebut adalah Allah "berada dalam diri manusia" atau "menyatu" dengan manusia. Atas dasar interpretasi inilah konsepsi al-ittihâd dalam tasawuf menjadi tidak mustahil. Akan tetapi "penyatuan" tersebut tidak dapat dikatakan bahwa manusia bersatu dalam diri Tuhan atau Tuhan mendiami tubuh manusia. Ungkapan tersebut sebetulnya untuk menggambarkan bahwa manusia "sangat dekat" dengan Tuhan.

Di samping hipotesis di atas, ada sudut pandang yang cukup menarik dikemukakan oleh Julian Baldick terkait konsepsi persatuan manusia dengan Tuhan sebagai berikut:

"Karena Islam tidak membenarkan kemungkinan kebersamaan Tuhan dalam diri manusia, maka muncul masalah serius untuk mendefinisikan mistisisme. Biasanya, mistisisme didefinisikan sebagai ajaran dan amalan menuju "persatuan dengan Tuhan." Akan tetapi kaum mistikus bukan hanya menolak konsep tersebut, melainkan juga menghujat konsep "persatuan" (al-ittihâd) di mana Tuhan dan manusia menjadi satu. Kata "persatuan" sering digunakan untuk menerjemahkan berbagai istilah Arab yang digunakan para sufi untuk menggambarkan pengalaman mereka. Padahal istilah tersebut lebih cocok 
diartikan sebagai "kebersamaan," "keikutsertaan," "singgah," "pertautan," dan "kesadaran akan Keesaan Tuhan" (Baldick 1992).

Definisi yang diberikan oleh Julian Baldick merupakan sebuah alternatif untuk menerjemahkan kata alittihâd. Istilah alittihâd dalam tasawuf memiliki makna yang cukup kompleks untuk disesuaikan dengan pandangan Islam secara umum. Di sisi lain, Islam menolak pandangan bahwa manusia bisa bersatu dengan Tuhan. Namun dalam pengertian tertentu, konsepsi tersebut juga memiliki landasan di dalam Islam.

Terlepas apakah kita sepakat atau tidak dengan pendapat Harun Nasution atau H.M. Rasjidi atau memiliki pendapat lain yang berbeda, beberapa penjelasan di atas bisa dijadikan solusi alternatif atau salah satu pijakan untuk menemukan jalan tengah agar kita dapat menyikapi polemik tersebut secara bijak.

\section{Simpulan}

Harun Nasution sebenarnya menyadari bahwa memang ada argumen yang mengatakan bahwa tasawuf berasal dari ajaran neoPlatonisme atau Kristen. Akan tetapi ia tampaknya tidak terlalu mempertimbangkan berbagai argumen bahwa tasawuf berasal dari luar Islam. Adapun H.M. Rasjidi percaya bahwa ajaran sufisme memang berasal dari luar Islam. Dengan demikian, disadari atau tidak, dalam masalah ini H.M. Rasjidi telah terpengaruh oleh cara pandang orientalis yang mengatakan bahwa ajaran sufisme berasal dari luar Islam sehingga dianggap tidak memiliki landasan di dalam Islam.

Harun Nasution ingin menunjukkan bahwa sufisme atau tasawuf merupakan aspek penting dari ajaran Islam. Sebagai akademisi, Harun Nasution secara jujur berusaha menampilkan setiap aspek dari ajaran sufisme termasuk konsep alittihâd atau keyakinan bahwa manusia dapat "bersatu dengan Tuhan." Harun Nasution mengakui bahwa "bersatu dengan Tuhan" merupakan tujuan utama dari sufisme. H.M. Rasjidi bersikap sebaliknya, ia bukan hanya menolak bahwa konsep al-ittihâd tidak memiliki landasan di dalam Islam, tetapi juga menolak jika dikatakan bahwa sufisme adalah salah satu aspek penting dari ajaran Islam. Kesimpulan Harun Nasution itu didasarkan pada pendekatan sufisme filosofis, sementara H.M. Rasjidi lebih menekankan hubungan manusia dengan tuhan ditinjau dari aspek formalistik. 
Pandangan Harun Nasution tentang legitimasi tasawuf yang menyimpulkan bahwa akar tradisi taswuf berasal dari ajaran intern Islam berimplikasi pada cara pandangan murid-murid dan pengikutnya bahwa tasawuf dapat diterima dan dapat dipahami secara filosofis. Sebaliknya, bagi para pendukung H.M. Rasjidi, tasawuf dianggap barang asing. Mereka cenderung untuk menjauhi pembahasan tasawuf yang bersifat filosofis.

\section{Daftar Pustaka}

Abdullah, M. Imron. 1997. "Islam Rasional Menurut Pemikiran Harun Nasution.” Tesis. IAIN Syarif Hidayatullah Jakarta.

Abdullah, M. Imron. 1999. "Perkembangan Teologi Rasional di Indonesia: Studi atas Pemikiran Pembaharuan Islam Harun Nasution." Disertasi. IAIN Syarif Hidayatullah Jakarta.

Afendi, Achmad Ruslan. 2010. "Peranan Harun Nasution dalam Pembaharuan Pendidikan Tinggi Islam di Indonesia.” Disertasi. IAIN Sunan Ampel Surabaya.

Alkhendra. 2006. "Pergulatan Pemikiran Islam di Indonesia: Studi terhadap Pemikiran Harun Nasution, Munawir Sjadzali dan Nurcholish Madjid.” Disertasi. UIN Syarif Hidayatullah Jakarta.

Ariendonika. 2002. "Pemikiran Harun Nasution tentang Islam Rasional." Disertasi. IAIN Syarif Hidayatullah Jakarta.

Bagir, Haidar. 2016. "Benarkah Tasawuf Bukan Berasal dari Islam?" https://islamindonesia.id (7 Desember 2018).

Baldick, Julian. 1992. Mystical Islam: An Introduction to Sufism. London: I.B. Tauris \& Co. Ltd.

Bisri. 2011. "Teologi Lingkungan (Model Pemikiran Harun Nasution dari Teologi Rasional kepada Tanggung Jawab Manusia terhadap Lingkungan)." Holistik: Journal for Islamic Social Sciences 12(1): 52 102.

Candra, Diki. 2018. "Akal dan Wahyu: Tela'ah atas Pemikiran Kalam Harun Nasution.” Jurnal Ad-Dirasah: Jurnal Hasil Pembelajaran IlmuIlmu Keislaman 1(1): 1-8. 
Faizin, Muhammad. 2018. "Gus Hayid: Ilmu Tasawuf Bukanlah Ilmu Sesat.” http://www.nu.or.id (7 Desember 2018).

Firdaus, Beni. 2010. "Pemikiran Harun Nasution tentang Ijtihad dan Perkembangan Hukum Islam." Al-Hurriyah: Jurnal Hukum Islam 11(2): 17-29.

Firdaus, Sukma Umbara Tirta. 2017. "Pembaharuan Pendidikan Islam Ala Harun Nasution (Sebuah Refleksi Akan Kerinduan "Keemasan Islam)." El-Furaqonia: Jurnal Ushuluddin dan Ilmu-Ilmu Keislaman 5(1): 167-84.

al-Ghazâlî. 1998. Ihyâa' 'Ulûm al-Dîn. Kairo: Dâr al-Hadîth.

Munir, Muammar. 2017. "Nurcholish Madjid dan Harun Nasution serta Pengaruh Pemikiran Filsafatnya." Petita: Jurnal Kajian Ilmu Hukum dan Syariah 2(2): 211-26.

Hilâl, Ibrâhîm. 1979. Al-Taṣawwuf al-Islâmî bayn al-Dîn wa al-Falsafah. Kairo: Dâr al-Nahḍah.

al-Husaini, 'Abdul 'Aziz bin 'Abdullah. 2013. "Ajaran Tasawuf Merusak Aqidah Islam.” https://almanhaj.or.id (7 Desember 2018).

Husnol, Muhammad. 2015. "Harun Nasution dan Pembaharuan Pemikiran Pendidikan Islam.” Tadrîs: Jurnal Pendidikan Islam 10(1): 24-28.

Hutasuhut, Efrianto. 2017. "Akal dan Wahyu dalam Islam (Perbandingan Pemikiran Harun Nasution dan Muhammad Abduh)." Al-Lubb: Jurnal Pemikiran Islam 2(1): 176-205.

Ibrahim. 2016. "Pemikiran Islam Kontemporer (Studi Kritis terhadap Pemikiran Harun Nasution)." Jurnal Aqidah 2(2): 99-110.

Jamal, Khairunnas. 2012. "Pemikiran Tafsir Harun Nasution (Studi Tentang Pola Penafsiran Al-Qur'an dalam Karya Tulis).” Jurnal Ushuluddin 18(1): 58-69.

Junni. 2004. "Pendidikan Akal Perspektif Harun Nasution." Tesis. UIN Syarif Hidayatullah Jakarta.

Lubis, Arbiyah. 2012. "Sunnatullah dalam Pandangan Harun Nasution dan Nurcholish Madjid.” Jurnal Ilmiah Islam Futura 11(2): 1-15. 
Mahmud, Agus. 1998. "Pembaharuan Islam di Indonesia: Suatu Tinjauan atas Gagasan Ijtihad Harun Nasution.” Tesis. IAIN Syarif Hidayatullah Jakarta.

Masrur, Muhammad. 2018. "Benarkah Tasawuf Bukan Bagian dari Syariat Islam?” https://bincangsyariah.com (7 Desember 2018).

Nasution, Harun. 1985. Islam Ditinjau dari Berbagai Aspeknya: Jilid II. Jakarta: UI-Press.

Nasution, Harun. 2010. Falsafat dan Mistisisme dalam Islam. Jakarta: Bulan Bintang.

Nasution, Harun. 2013. Islam Ditinjau dari Berbagai Aspeknya, Jilid I. Jakarta: UI-Press.

Rasjidi, H.M. 1972. Koreksi terhadap Dr. Nurcholis Madjid tentang Sekularisasi. Jakarta: Bulan Bintang.

Rasjidi H.M. 1997. Koreksi terhadap Dr. Harun Nasution Tentang "Islam Ditinjau dari Berbagai Aspeknya." Jakarta: Bulan Bintang.

Rosyid, Moh. 2018. "Mengidentifikasi Kemuktabarahan Tarekat Syahadatain." Ulul Albab: Jurnal Studi Islam 19(1): 98-118.

Ruwaifi' bin Sulaimi. 2011. "Mewaspadai Sufi." http://asysyariah.com (7 Desember 2018).

al-Qushayrî. 2013. Al-Risâlat al-Qushayriyyah. Beirut: Dâr al-Kutub al'Ilmiyyah.

Salahuddin, Dicky. 2000. "Konsep Pendidikan Islam Menurut Harun Nasution.” Tesis. Universitas Muhammadiyah Jakarta.

Schimmel, Annemarie. 2003. Dimensi Mistik dalam Islam. Terj. Sapardi Djoko Damono. Jakarta: Pustaka Firdaus.

Sholehuddin, M. Sugeng. 2010. "Reinventing Pendidikan Islam Harun Nasution." Forum Tarbiyah 8(1): 119-29.

Smith, Margaret. 2007. Mistisisme Islam dan Kristen: Sejarah Awal dan Perkembangannya. Terj. Amroeni Drajat. Jakarta: Gaya Media Pratama. 
Syakur, Abdus. 2015 "Polemik Harun Nasution-H.M. Rasjidi dalam Falsafat dan Teologi." Ilmu Ushuluddin 2(4): 371-88.

Syarief, Nasruddin. 2013. "Pemikiran H.M. Rasjidi tentang Metodologi Pendidikan Islam di Indonesia." Disertasi. Universitas Ibnu Khaldun Bogor.

Syefriyeni. 2013. Relativisme Etika: Studi Perdebatan Sekularisasi antara Nurcholish Madjid dan H.M. Rasjidi. Ciputat: Pustaka Anak Negeri.

al-Taftazânî, Abû Wafâ’ al-Ghanîmî. 2008. Tasawuf Islam. Terj. Subkan. Jakarta: Gaya Media Pratama.

Wahyudi, Ari. 2008. "Sufi: Benarkah itu Ajaran Nabi?" https://muslim.or.id (7 Desember 2018).

Yanti, Depi. 2017. "Konsep Akal dalam Perspektif Harun Nasution.” Jurnal Intelektualita: Keislaman, Sosial, dan Sains 6(1): 51-62. 